\title{
Building Maintenance Management in a Malaysian University Campuses: A Case Study
}

Olanrewaju Abdul Lateef, Mohd Faris Khamidi and Arazi Idrus, (Department of Civil Engineering, Universiti Teknologi PETRONAS)

\begin{abstract}
University buildings require maintenance in order to create a conducive environment that supports and stimulates learning, teaching, innovation, and research. The prime objective of maintenance is to ensure, as far as practicable, the continued peak performance of the building throughout its design life. This paper seeks to report the maintenance management system of a university institution in Malaysia. Primary data was gathered through the analysis of a case study. The objectives of the case study are to identify, describe and assess the maintenance management system used by the university. The major conclusion drawn from the case study was that although university building maintenance practices are corrective and cyclical there is a lack of a comprehensive maintenance management framework that guides the decision-making processes. The case study also revealed irregularities in the university's maintenance management system.
\end{abstract}

Keywords: Service delivery, University buildings, Maintenance management, Maintenance, Malaysia

\section{Introduction}

Maintenance means different things to different people. The term has been defined and redefined by different authors. However, the various definitions suggest that maintenance revolves around building care. Nevertheless, in this paper maintenance is defined as the required processes and services undertaken to preserve, protect, enhance and care for the university buildings' fabrics and services after completion, in accordance with the prevailing standards to enable the building and services to serve their intended functions throughout their entire life span without drastically upsetting their basic features and uses. University buildings are a factor of production; they are used to produce future leaders, captains of industry, entrepreneurs, scientists, engineers and managers. A building is an asset whose value changes in accordance with the quality (and quantity) of maintenance invested in them. This paper illustrates with a case study how a university organization manages its maintenance services in Malaysia. The word "model" in the research is synonymous with the decision-making framework or guidelines for managing university buildings maintenance. Thus, a university building maintenance management model means a decision-making framework for the maintenance of university buildings. In this context, the model consists of personnel, procedures (and materials, tools, equipment and facilities), activities, tasks and guidelines. This paper proceeds in Section 2 to reviewing the existing literature on building maintenance procedures in Malaysia. In Section 3, the research design and methodology are described. The fourth section of the paper introduces a case study in which the maintenance management of a university is assessed, evaluated and discussed. This analysis provides insight on various procedures of the university building maintenance system. Section 5 presents the summary of the observations made on the case study. The concluding remarks are provided in Section 6.

\section{Literature Review on University Building Maintenance Management in Malaysia} Education is a very significant and integral part of the Malaysian Strategic Thrust. The economy of Malaysia has since independence been planned on five year strategic plans. In each of the plans, the education sector features prominently in terms of value and policy 
implementations. There has been an expansion of more than $420 \%$ in allocation to the education sector for the last 20 years. See Table 1 for the Federal Development allocations to the education sector from 1990 to 2010. The increase in the allocations is part of the Government's commitment to improve the performance of the education system in order to produce human capital with intellectuals capable of competing locally and internationally (Ministry of Higher Education, 2006). The allocation to the education sector $2.1 \%$ of the GDP (Ministry of Higher Education, 2006).

\begin{tabular}{|c|c|c|c|c|}
\hline \multicolumn{7}{|c|}{ (RM Million) } \\
\hline Sectors & $\mathbf{6 M P}$ & $\mathbf{7 M P}$ & $\mathbf{8 M P}$ & $\mathbf{9 M P}$ \\
\hline Education & $7,469.8$ & $17,948.5$ & 18,660 & $40,356.5$ \\
\hline Training & 615.4 & $2,237.3$ & 4,000 & $4,792.6$ \\
\hline Total & $\mathbf{8 , 6 2 5 . 2}$ & $\mathbf{2 0 , 1 8 5 . 8}$ & $\mathbf{2 2 , 6 6 0}$ & $\mathbf{4 5 , 1 4 9 . 1}$ \\
\hline
\end{tabular}

Table 1 Development allocations for the educational and training sectors (Government of Malaysia, 1996, 2001, 2006)

In tandem with the expansion in the allocations to the education sector at all levels, the allocations at the tertiary level are also increasing substantially. As an illustration, under the Eighth Malaysian Plan, the sum of RM8, 900 million was allocated to institutions of higher learning out of the RM18, 660 million allocated to the education sector (Government of Malaysia, 2001) while under the Ninth Malaysian Plan, allocation to institutions of higher learning was increased to RM16,069 million (Government of Malaysia, 2006). This represents an increase of more than $80 \%$. As a percentage of total public expenditure, $4.4 \%$ was attributable to the higher institutions of learning (Ministry of Higher Education, 2006). Higher education in Malaysia is both a source of employment as well as source of foreign exchange and it is gradually becoming a major contributor to the economic sector and becoming a strong export source (Ministry of Higher Education, 2006). Malaysia is now an educational destination to nationals from different countries particularly those from Africa, the Middle East, Pacific and other Asian countries. Malaysia's quest to transform into a knowledge based economy (K-economy) where science, technology, and engineering are integrated into the production process. This is also where creativity, imagination, and design capability are embodied in well-educated skilled workers who are the main source of national prosperity and wealth is not open to compromise (Government of Malaysia, 2006). In order to achieve this objective however, the assets of the universities must be adequate in all respects. University buildings constitute a significant part of the assets. These buildings and the associated engineering services require maintenance. University buildings are procured to create a suitable, conducive and adequate environment that can support, stimulate and encourage learning, teaching, innovation and research activities. A failure in the supply of these essential services is a loss in value of the building to the university institution, the community, the students, staff and other stakeholders. Recent studies (Housley, 1997; Fleming and Storr, 1999; Amaratunga and Baldry, 2000; Price, Matzdorf, Smith and Agahi, 2003; Green and Turrell, 2005; Leung and Fung, 2005; Wong, Fellows and Liu, 2007; Fianchini, 2007 and Lavy and Bilbo, 2009) have affirmed the positive correlations between performance of educational buildings and quality of education. It is through the university buildings, that future leaders, captains of industry, entrepreneurs, professionals and scientists are produced (Mat, et al., 2009). Universities these days use the nature, design and condition of their buildings to entice students. In Malaysia, universities that in the past relied on the applications sent to them through the Ministry of Education, now use their buildings as a variable to attract students (Rohaizat, 2002 and Yosuf, Ahmad, Tajudin and Ravindran, 2008).

Constructing new buildings helps to upgrade educational facilities and provide a better quality of education, but it is also necessary to maintain the existing buildings to an

Lateef, O A, Khamidi, M F and Idrus, A (2010) 'Building maintenance management in a Malaysian university campuses: a case study', Australasian Journal of Construction Economics and Building, 10 (1/2) 76-89 
acceptable performance standard that is capable of facilitating the transfer of knowledge and other academic activities. Thus, with any inadequacy of the building facilities, the prime objective of the university will be difficult if not impossible to achieve. Therefore, a well maintained building is critical to delivering university core business objectives. While there is a concerted effort in increasing the allocation for the maintenance of public infrastructure assets and facilities, there is also a corresponding increase in the maintenance of university buildings. Under the Sixth, Seventh and Eighth Plans, allocation for maintenance and upgrading as a percentage of the development allocation was $0.2 \%$ under each of the Plans, while under the Ninth Plan, the allocation increased substantially to $0.5 \%$. This marked an increment of $150 \%$. In financial terms, the allocations increased from RM 101 million under the Sixth Plan to RM 203.2 million under the Seventh Plan. This is an expansion of about $100 \%$. Further, there was some 6\% expansion under the Eighth Plan compared to that of the Seventh Plan. However, under the Ninth Plan, it further increased from the RM 214.5 million to RM 1,079 million, an expansion of some $403 \%$. In addition, the Government has pledged to give more attention to the maintenance of buildings and other infrastructural facilities. However, there is no comparable numerical data on the exact allocations to the maintenance of university buildings, however based on inconclusive data obtained from the Ministry of Higher Education, it suggests that maintenance expenditure has expanded by nearly $85 \%$ from 2004 to 2008. For instance, expenditure on maintenance was nearly RM 340 million in 2004 while it increased to more than RM 600 million in 2008 even though the figure for 2008 was the same as July 2008. See Table 2 for the breakdown. However, discussions with those concerned in the management of university building maintenance revealed a concern about the amount of funding universities wish to have compared to the amount of funding they are actually receiving. While there is no comparable numerical data on private universities' investment on maintenance, it would not be difficult to conclude that they also spend substantial parts of their expenditure on building maintenance just like the public universities, if not more.

\begin{tabular}{|c|r|}
\hline & (RM Million) \\
\hline Year & Expenditure RM \\
\hline 2004 & $338,529,567$ \\
\hline 2005 & $470,480,191$ \\
\hline 2006 & $508,921,700$ \\
\hline 2007 & $580,491,662$ \\
\hline 2008 & $619,229,160$ \\
\hline Total & $\mathbf{2 , 5 1 7 , 6 5 2 , 2 8 0}$ \\
\hline
\end{tabular}

Table 2 Expenditure on Maintenance of Public University Buildings, (Source: Adapted from data obtained from the Ministry of Higher Education, Malaysia)

However, it is doubtful whether a solution can be found with increases in the allocation to the maintenance sector, but a proactive and systematic approach to maintenance will go a long way in achieving best value for money invested. It will not be very difficult to argue that maintenance as a technique or science is not the problem per se; rather it is the management of the maintenance service. Maintenance management seeks to plan, control, coordinate and organize maintenance activities focusing on efficient allocation and utilization of resources in order to improve the value of a building. In other words, it is procedure and process that is used to achieve effectiveness (increase user satisfactions) and efficiency (with optimum resource) in service. Proper maintenance management has effect on the reliability, safety, availability and quality of the building. However, efficient and effective maintenance depends on the availability of information on the criteria that influences university building maintenance, criteria that influences users' satisfaction in university building, nature of defects in university buildings and maintenance performance metrics for the university buildings. With this information, university building maintenance would be more efficiently and effectively initiated and implemented as compared to how it is currently executed.

Lateef, O A, Khamidi, M F and Idrus, A (2010) 'Building maintenance management in a Malaysian university campuses: a case study', Australasian Journal of Construction Economics and Building, 10 (1/2) 76-89 


\section{Research Design and Methodology}

The research integrates a literature review and a case study. While the literature review provides an overview of building maintenance practices, the case study provides qualitative and contextual data on the building maintenance procedures of a typical university organization in Malaysia. There are various methods to collect research data. The method to use for the research depends on the nature of the information required and other prevailing circumstances pertaining to the topic and the study area. The case study approach is a very useful tool to collect detailed and contextual information. It gives an opportunity to delve into one aspect of a problem in more detail within a limited timeframe (Bell, 2005). According to Bell (2005), the case study approach seeks "to put flesh on the bones of a survey research. Much of the information for case study strategy is derived from documentation and archival analyses. For instance, documents that could be analysed for maintenance management include periodic reports, minutes of meetings, specialists' contractual agreements, previous maintenance records and complaint records. However, a major shortcoming of the case study approach is that of generalization of the findings from the particular case studied to other cases even though they may be similar. Critics of the approach also believe that there is always a tendency for data distortion since there is no yardstick for data comparison and critics also argued that the approach is very selective (Bell, 2005). However, proponents of the case study approach disagreed arguing that the extent of such generalizations depends on the similarity of the case, and the methodology employed in data organization, collection and analysis (Bell, 2005). In fact, there is sufficient evidence to suggest that the findings of the case study can be generalized. According to Komu (2008), it is not the sample size in research that determines the scientific rigor but the consistent and systematic approach and fitness for purpose that matters. McNiff (1992) also opinioned that, although the case study approach is time consuming, the data obtained is accurate and representative of the case studied. In using the case study approach, various techniques including the interview, survey, observation and experimentation can be used. Through the case study approach, the corporate structures, and the information management of the organization under study, can be well understood (Barker, 2005). Therefore, considering the nature of the information required vis-à-vis the current arrangement of the organization that is studied, it will not be difficult to conclude that the case study approach is appropriate for this study. Following, Naoum's classification of the types of case study design; this particular case study is explanatory in nature (Naoum, 2007). This is because it is the intention of this study to explore the maintenance management procedures of the university organization in Malaysia. The relationship for this study is shown in Figure 1.

\begin{tabular}{|c|c|l|}
\hline $\begin{array}{c}\text { Maintenance } \\
\text { management system }\end{array}$ & is related to & $\begin{array}{l}\text { Poor service delivery } \\
\text { Poor user satisfaction } \\
\text { Maintenance backlogs }\end{array}$ \\
\hline
\end{tabular}

Figure 1 A schematic diagram showing the relationship between maintenance management systems and poor service delivery, poor user satisfaction and maintenance backlogs

\section{Case Study of University Building Maintenance Management}

This section illustrates how a university organization manages the maintenance of their buildings and engineering service maintenance. In this particular university, the Property and Maintenance Management Department (PMMD) is responsible for the management of all the university's physical assets. The mission of the PMMD, as contained in the university's guidelines, is to deliver comprehensive property management and maintenance services to support the university's vision and mission as well as its HSE policy. The Maintenance Unit is responsible for maintenance of buildings, engineering services and the landscaping. The unit is also responsible for the provision of management services for minor refurbishment.

Lateef, O A, Khamidi, M F and Idrus, A (2010) 'Building maintenance management in a Malaysian university campuses: a case study', Australasian Journal of Construction Economics and Building, 10 (1/2) 76-89 


\begin{tabular}{|l|c|c|}
\hline Position & No & Percentage \\
\hline General Manager & 1 & 5.6 \\
\hline Electrical Executive & 1 & 5.6 \\
\hline Mechanical Executive & 1 & 5.6 \\
\hline Civil Executive & 1 & 5.6 \\
\hline Technical Assistants & 11 & 49.8 \\
\hline Clergyman & 2 & 11.6 \\
\hline Landscape Architect & 1 & 5.6 \\
\hline Property manager & 1 & 5.6 \\
\hline Clerk & 1 & 5.6 \\
\hline Total & $\mathbf{1 8}$ & $\mathbf{1 0 0}$ \\
\hline
\end{tabular}

Table 3 Work Force / Strength (Source: Analysis of data obtained from PMMD, 2008)

The case study commenced on $26^{\text {th }}$ of March, 2009 and was completed on $2^{\text {nd }}$ of April, 2009. The maintenance organization is headed by a general manager, who is assisted by five executive officers one each for the mechanical, electrical, civil, property and landscaping units. The property executive is responsible for the general management of all the university's physical assets. The other four executive officers are responsible for the maintenance of the building structures and services and the landscaping. However, this paper is only concerned with the electrical, mechanical and civil engineering works. The services provided by the other two executives are beyond the scope of this paper. Each of the executive officers possess a Bachelor's degree in their area of specialization. None of them possess a postgraduate degree. They have being working in those capacities for a period ranging from four to ten years. Each of the maintenance executives were assisted by a varying number of technicians. Some of the technicians hold diplomas while the others only hold secondary school certificates. However, in the case of the electrical unit, in addition to three assistants, there were also clergymen. Administratively, the clergymen are superior to the technicians. Table 3 shows the staff strength of the department. See also Figure 2 for the organizational chart.

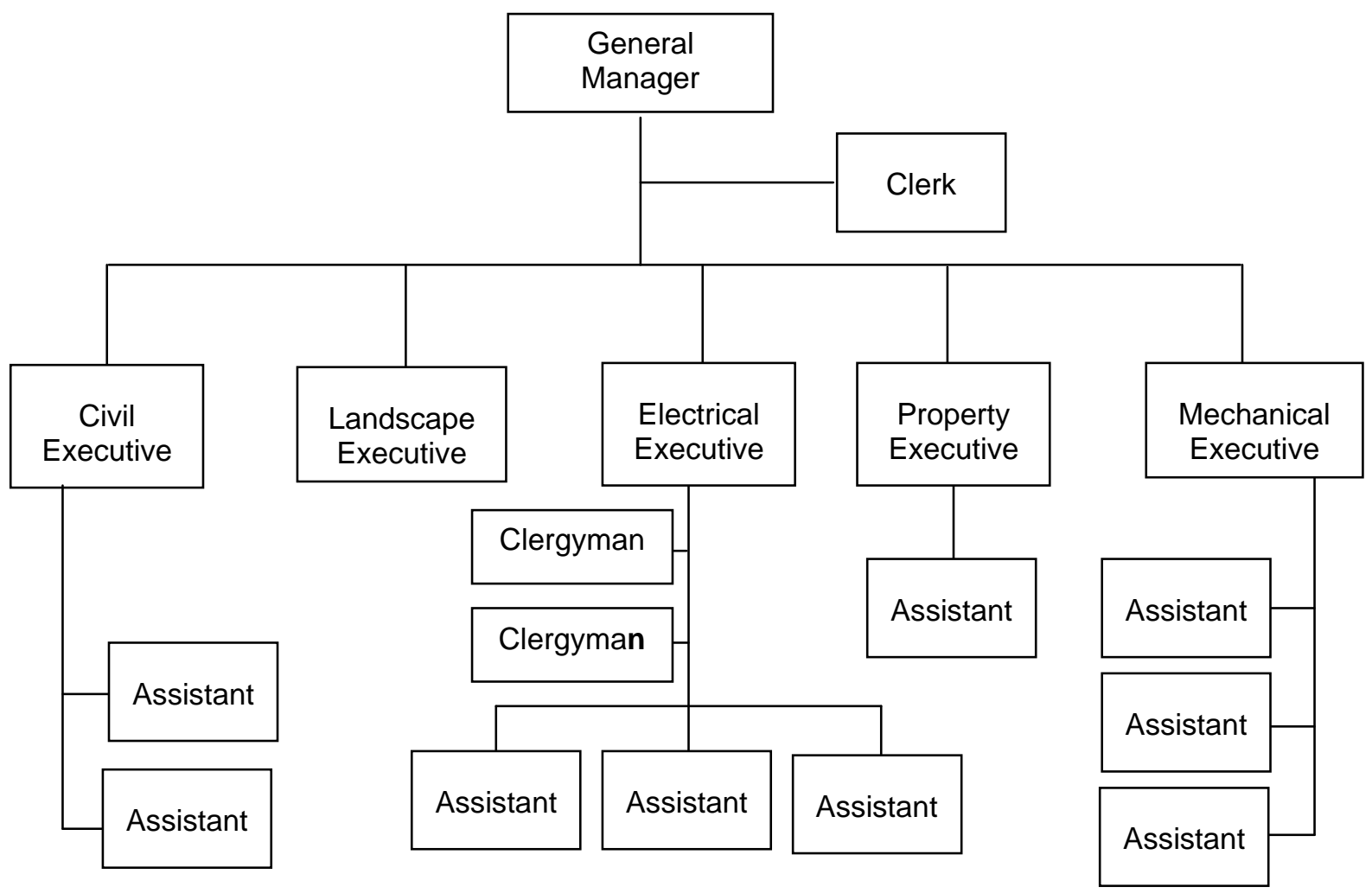

Figure 2 Structure of the Organization Chart (Source: Adapted from chart obtained from PMMD, 2008)

Lateef, O A, Khamidi, M F and Idrus, A (2010) 'Building maintenance management in a Malaysian university campuses: a case study', Australasian Journal of Construction Economics and Building, 10 (1/2) 76-89 
The case study was initially designed to be conducted in the form of a focus group where all the maintenance executives and the researchers would attend. However, the attempt failed due to the executives' schedules, it became impossible to have them together in a forum. As a result, it was concluded to meet with them one by one for semi-structured interviews. Altogether, there are three members in the research team, with one main researcher. Before the main case study was conducted; the researchers' organization formally wrote a letter to the maintenance organization asking for their corporation on the research. They were assured of high confidentiality with all information provided to the researchers. Before the interviews, suitable dates were agreed with each of the executives, this was to avoid or reduce the likelihood of not meeting with the executives at the appointed dates. Beside the interviews, there were a series of follow-ups for further clarification through SMS, telephone conversations and e-mail. In the semi-structured interviews, the interviewer asked questions pertaining to the topic under investigation and then recorded the respondents' responses. Based on the responses, supplementary questions were asked where necessary. This involved prompting the interviewee (Fellows and Liu, 2008). On average, the interviews took about 45 minutes with each of the respondents. These were apart from the "casual" discussions carried out prior to the formal interviews. The executives were asked a set of pre-determined questions on the maintenance management procedures they were using. However, they refused to provide answers to some of the questions that were addressed to them. They considered such information as sensitive and personal. For instance, when they were asked how much do they receive per annum for maintenance, the researchers were directed to the University Finance Unit. However, even though an effort was made to contact the Finance Unit, they were unable to provide the required information. According to them such information cannot be divulged to an "external party". They submitted that such information was strictly for the university management as it was proprietary or classified information. The major pre-determined questions that were addressed to the respondents included:

- What is your current position?

- How long have you been working in this position?

- What is the size of the built up area of the university?

- What is your approximate annual budget for maintenance?

- How do you estimate your annual building maintenance budget?

- Is your budget allocation sufficient for the complaints that you receive?

- In case you run into deficit, how do you make it up?

- Which of the maintenance approaches do you use?

- Have you conducted any user satisfaction surveys?

- If so, what was the outcome of the survey?

- How do you think the current maintenance management system can be improved?

For purposes of confidentiality, the identity of the university was not given while other information provided was factual. Any other information that could reveal the identity of the university was not mentioned. The university integrates old and new buildings and has been operating in the old buildings whilst awaiting the completion of the new buildings. The old buildings previously served as the satellite campus for a different university. Prior to commencing operations in the old buildings, there were mass refurbishment, conversion and maintenance activities. This was to enable the buildings and the associated facilities to perform their intended functions. While the old buildings are about 25 years old, the new ones are less than ten years old. The new buildings were constructed and equipped with state-of-the-art material and equipment. There are about 7000 students comprising both postgraduate and undergraduate students on the campus and about 300 academic and nonacademic staff. More than $90 \%$ of the students live on campus.

Lateef, O A, Khamidi, M F and Idrus, A (2010) 'Building maintenance management in a Malaysian university campuses: a case study', Australasian Journal of Construction Economics and Building, 10 (1/2) 76-89 
Based on documentary and archival analyses it was found that the buildings cover about $40,000 \mathrm{~m} 2$ in built-up area, altogether comprising 111 buildings of various sizes with different functions. It was also gathered that there were 34 lifts in the university that are concentrated in the academic, laboratory and administrative buildings and there are 149 air-handling units in addition to about 700 split air conditioning units. Generally, all maintenance work, whether it is electrical, civil or mechanical in nature, is classified into major jobs and minor jobs. Small contractors operate on a price agreement basis (i.e. electrical maintenance price agreement, civil maintenance price agreement and mechanical maintenance price agreement). Under the agreement, a contractor will quote a unit price for specific items of work that will be executed in one operating year. For instance, it will be agreed on how much it will cost the contractor to fix a new bulb or to repair a door lock. During the specified period, a contractor cannot ask for an increase in price and neither can the university demand a price reduction. At the end of each operating year; when the agreement expires, tenders will be open for suitable contractors to bid for the works from which some will be selected based on their quoted price. The existing contractors can also participate if they so wish. Contractors are selected on the advice of the respective executive officers. For example, the electrical executive will vet the electrical contractors' quotations to recommend the selection of a contractor to the general manager. The major works are the types of works that are managed using other strategies like the traditional procurement strategies. For instance, work will be advertised through various means, inviting contractors to bid for the work and the tender will be awarded to a contactor(s) that is/are selected. So far, the maintenance organization has not used modern procurement systems like Public Private Partnership in their building and services maintenance.

For operational purposes, the maintenance department has categorized the buildings into administrative buildings, libraries, staff accommodation, offices and hostels, laboratories, workshops, and other supporting facilities. The building maintenance management revolves around a cyclical and corrective maintenance program. On average, for the last five years, the university spent RM15 million on the maintenance of constructed facilities each year. The official working hours are $8.00 \mathrm{am}$ to $5.00 \mathrm{pm}$ daily, Monday to Friday. The department does not open for business on Saturday and Sunday and all Public Holidays. All maintenance complaints that arise on Saturday and Sunday are attended to on the next working day. Complaints on maintenance are lodged through the warden for each of the hostels while complaints concerning the other buildings are lodged through the technicians in the control room by the users (i.e. lecturers and laboratory attendants). The control room is located in the administrative buildings. If say, there is a problem in a classroom, the lecturer or whoever is in charge of the classroom will call the control room. Depending on the type of complaint, the technician will visit the place and issue a docket. If it is an electrical failure, an electrician will inspect and issue a docket that will be passed on to the Head Office for necessary action. Students are not allowed to make complaints directly to the maintenance unit. Instead, students will have to lodge complaints through the warden and the warden, in turn, lodges the complaint to the respective executive at the Head Office. For instance, whenever there is a complaint from the user, the warden will fill in a docket and send it to the maintenance department. A booklet of dockets contains 100 complaint sheets. The maintenance department will, in turn, send it to a contractor to submit a quotation. The docket contains the complainant's name, a description of the complaint and location of the defect. Usually, it takes a minimum of 24 hours for the maintenance department to settle the work with the contractor concerned. Complaints received after 5:00pm are directed to the assistant engineers at the control room and will be treated on the following working day. The clerk receives all dockets daily and sends them to the respective executive. All work including filing and sorting are done using traditional computer programs like Microsoft Word and Excel.

Maintenance complaints are responded to based on their urgency. Table 4 describes the response time for the different complaints categories. The response time is the time that the

Lateef, O A, Khamidi, M F and Idrus, A (2010) 'Building maintenance management in a Malaysian university campuses: a case study', Australasian Journal of Construction Economics and Building, 10 (1/2) 76-89 
maintenance team takes to respond to the call for maintenance and not for completing the task requested. The priority P1 is the category of work that will cause loss of business to the university. For instance, maintenance that will disrupt or disturb classes, and this category of work is attended to within 24 hours. See Figure 3 for the complaint reporting procedure. The Figure shows the activities involved from the time that a complaint is received to when the job is completed. All complaints are made by phone, email, or their combination.

\begin{tabular}{|c|c|c|}
\hline Priority & Categories & Response Time \\
\hline $\begin{array}{l}\text { Priority } 1 \\
\text { (Urgent) }\end{array}$ & $\begin{array}{l}\text { Serious safety hazard / incident } \\
\text { Irreplaceable / catastrophic loss to the } \\
\text { university business operations, } \\
\text { teaching and research } \\
\text { Serious asset damage (e.g. fire/ major } \\
\text { leaks which may include water, gas } \\
\text { Widespread loss of power }\end{array}$ & $\begin{array}{l}\text { Within } 15 \text { minutes } \\
\text { (during normal working hours) } \\
\text { Within } 30 \text { minutes } \\
\text { (after working hours) }\end{array}$ \\
\hline $\begin{array}{l}\text { Priority } 2 \\
\text { (Normal) }\end{array}$ & $\begin{array}{l}\text { Low risk safety hazards } \\
\text { Malfunction of equipment } \\
\text { Asset requires maintenance - not } \\
\text { urgent } \\
\text { Minimal risk to teaching and research } \\
\text { operations }\end{array}$ & $\begin{array}{l}\text { Within } 1 \text { hour (during normal } \\
\text { working hour) } \\
\text { Within } 2 \text { working days } \\
\text { (after working hours) }\end{array}$ \\
\hline $\begin{array}{l}\text { Priority } 3 \\
\text { (Cyclical) }\end{array}$ & $\begin{array}{l}\text { Routine maintenance } \\
\text { Program work } \\
\text { Work scheduled as per agreement with } \\
\text { customers }\end{array}$ & $\begin{array}{l}\text { No specified response time } \\
\text { Jobs in these categories are usually } \\
\text { reserved for future execution, the } \\
\text { duration of which depends on the } \\
\text { volume of works and availability of } \\
\text { budget. It could take a year or more }\end{array}$ \\
\hline
\end{tabular}

Table 4 Response Time (Source: Adapted from data obtained from the PMMD, 2008)

Specifically, electrical maintenance procedures comprise of corrective, inspection and statutory maintenance. Statutory maintenance is the type of maintenance that arises as a result of a law governing the performance of buildings and services in Malaysia (i.e. Electricity Act 1990 and Electricity Regulation 1994). It is done for calibration of protection relay. Protective relays are used to detect faults in major equipment. It is conducted on equipment every two years. On average, the electrical unit receives 30 complaints daily, albeit with a slight increase on Mondays, apparently because of the backlogs of complaints from the previous Saturday and Sunday. The electrical unit has one electrical engineer, two clergymen and three assistant technicians (Figure 1). More than 95\% of the electrical work is out-sourced. The in-house operatives only entertain minor works like changing of bulbs and sockets. The mechanical installations are maintained correctively, preventively and statutorily. The preventive maintenance involves inspecting the equipment bearings, greasing, checking power load for motors and cleaning the filters of the air-handling units every two months. However, apparently due to the age of the equipments, the mechanical equipment in the old building generates more complaints than in the new buildings. All maintenance that relates to the mechanical unit is $100 \%$ outsourced unlike in the case of the electrical work.

Work that falls under the civil unit includes buildings, water supply, sewage, piping, pest control, general building cleaning and sanitary / hygienic services. Maintenance work is mainly corrective and cyclical. More than $95 \%$ of the work is cyclical and corrective based maintenance. Work categorized as cyclical maintenance includes painting and the changing of door locks. Walls are painted every five years. However, this is subject to the availability

Lateef, O A, Khamidi, M F and Idrus, A (2010) 'Building maintenance management in a Malaysian university campuses: a case study', Australasian Journal of Construction Economics and Building, 10 (1/2) 76-89 
of funds. The unit entertains about 30 complaints daily and the most frequent complaints include clogging, problems related to water supply, safety issues, doors and door locks. Likewise, there is an increase in complaints on Mondays. Interestingly, fewer maintenance problems emanate from the old buildings than from the new buildings. Arguably, a likely reason for this is the quality of materials and workmanship. For instance, the wood used for the construction of the old buildings was of high quality compared to the wood used in the new buildings (with specific reference to the hostels). The big contractors execute works like renovation, major repairs, and the small contractors do alterations and small jobs like the minor repairs.

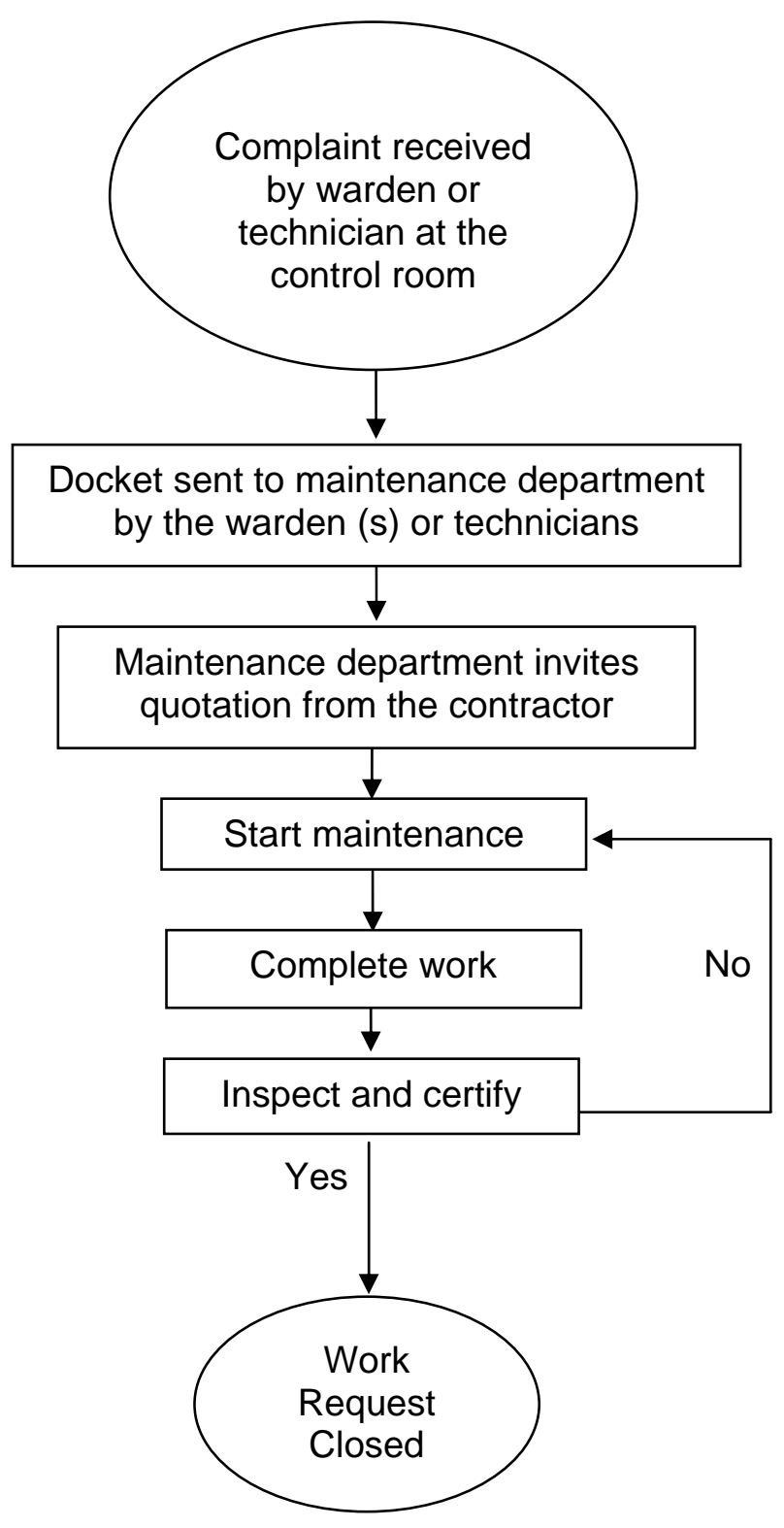

Figure 3 Maintenance work reporting procedures (Source: Adapted from the data obtained from PMMD, 2008)

\section{Summary and Observations}

In summary, based on the case study, the following observations are made: 
1. The maintenance management systems are not IT based. The Computerized Maintenance Management System (CMMS).is not used. All works are done using the traditional computing process through Microsoft Word and Excel (Windows 97). The CMMS is a software package that keeps a computer database of information of the organization's maintenance operations. It enables the maintenance organization and their customers to track the status of maintenance work on their assets. Essentially it facilitates the decision making process of assets maintenance. Tasks that were traditionally done through paper works are done using the software. The traditional method wastes a lot of time, effort and materials. According to $\mathrm{Ng}$, Gable and Chan (2002), time may be wasted on iterative data gathering and service delivery. Services including data analysis, tracking of complaints, and workforce distribution can better be handled by a CMMS which can lead to tremendous savings in money and time.

2. The current maintenance management system is mainly corrective and cyclical. These approaches to maintenance have been criticized for various inadequacies. They lead to maintenance backlogs and poor user satisfaction.

3. There are no clear key performance indicators. Thus, control functions cannot be optimized. In this situation, it will be difficult to make improvements since improvement in user satisfaction and productivity cannot be measured or monitored for necessary improvements. There is the need for a mechanism for measuring performance. The maintenance organization needs to develop or adopt a performance metric that could be used to benchmark their service with what other similar organizations provide to the customers for a meaningful comparison and for improvement.

4. The maintenance department is understaffed and the staff are also inadequately qualified. Perhaps it could be expected that professionals including architects and quantity surveyors be employed to advise on aspects that relate to their specialization. For instance, a quantity surveyor could provide professional advice on alternative procurement strategies and make decisions on contractual matters while the architect is also in charge of the building works. Presently, the building works are categorized under the civil engineering works. The person in charge has his background in civil engineering. Although, during the interview, he claimed to possess the required knowledge and expertise to manage the maintenance of buildings. However, this may not be entirely correct withstanding his working experience. However, much (nearly 90\%) of the maintenance complaints he received relate to building and not civil engineering works. There is duplication of responsibilities particularly in the electrical unit; the function of the technician and the clergymen is not clearly defined. Other than the fact that a clergyman is technically superior to the technician in rank, their functions overlapped leading to duplication of responsibilities. The clergymen perform some of the functions of the electrical engineer while also giving instructions to the technicians on certain tasks. From observation there is no need for the middle (clergyman) men.

5. The maintenance is budget-driven rather than needs-driven. Maintenance is initiated subject to the availability of funds and in many cases cyclical maintenance is put off until such time that funding is available to perform the tasks.

6. Although the funding allocated to maintenance may not be sufficient, it is equally clear that the available budget is not effectively or efficiently managed. Thus, maintenance cannot be blamed but it is the management system that should be blamed. For instance, even if all the work is carried out correctively, it still requires some more systematic and cost-effective approaches than those currently used.

7. The outsourcing approach is very rudimentary and haphazard. The contractors do not even have offices on the campus. They only come when there is work for them to do. On the one hand, there are some (Martin, 1997 and Campbell, 1995) who believe that organizations like universities have nothing to do with maintenance since building maintenance is outside the scope of their core services and, therefore, they should outsource such facilitative functions. On the other hand, there are also quite a

Lateef, O A, Khamidi, M F and Idrus, A (2010) 'Building maintenance management in a Malaysian university campuses: a case study', Australasian Journal of Construction Economics and Building, 10 (1/2) 76-89 
number of authors (Sherwin, 2002) who do not entirely agree with them. The opponents of the strategy believe that even though some aspects of maintenance could lend themselves to outsourcing, not all work can be outsourced. Shortcomings of outsourcing include loss of skills, loss of control, and exposing the organization to threats by suppliers of maintenance services (Shohet et al., 2003). From the study, it could be inferred that outsourcing of the maintenance function reduces maintenance to corrective maintenance and increases maintenance backlogs. There is also some organizational political-proprietary information that the university would not like to expose to external parties. Tsang (2002) warned against organizations outsourcing facilitating functions like maintenance. He also warned organizations not to consider outsourcing activities that are critical to their core activities. No doubt building maintenance is very critical to the continuous existence of a university. However, decisions on what to outsource should be based on objective and quantitative facts even though a situation where a university outsources about $95 \%$ of its services may not be entirely healthy for any organization. In the opinion of Sherwin (2002), it is still too early to say outsourcing maintenance services is an alternative approach to maintenance service delivery. Times have changed. It is high time university organizations accept and take care of their buildings (vis-à-vis the maintenance practices) efficiently. It is no longer acceptable for a university to invest only on improving methods of teaching and learning without improving other assets. Universities should invest on training their maintenance staff as they would academic staff. It is a failing on the part of the university management to consider the management of their buildings as non-core activities. It is contended that maintenance is also a core activity of the university organizations, since without it the university would not survive. Maintenance is inevitable in the building life cycle, thereby assuming a strategic position and function in the building performance. For organizations that pay millions of dollars to acquire the building facilities to claim that it is not their core function is a failing on their part.

8. Universities must take care of their interrelated assets namely; buildings, technology and human resources for better performance, a failing in one will also affect the others.

9. The reporting system is fragmented and complicated; there is a need for a single point of contact to report all problems. Fragmentation will encourage delays and increase maintenance costs unnecessarily and worsen building users' frustration and disappointment.

10. Not working at all on Saturdays and Sundays is another serious inadequacy from a management perspective. Provision should be made for technicians to be available to assist students in the hostel during the weekend. This would also reduce maintenance backlogs on the following Monday or the next working day. In fact, it is apparent on these days that many students only have the time to report complaints because often there are no scheduled classes on Saturdays and Sunday. Except for some of the postgraduate students, most of the students spent most of their time in classrooms, laboratories or and libraries Monday to Friday with only Saturday and Sunday left for defect identification days.

11. The technicians were merely performing clerical functions, leading to under utilizations of staff. They perform administrative functions such as receiving calls on maintenance requests; doing paper work and collating data to be delivered to the respective maintenance executive. The technicians ought to be performing technical tasks. The job of the clerk is to perform the secretariat duties.

12. There is no feedback mechanism on users' satisfactions. The maintenance organizations of universities seldom carry out user satisfaction surveys. This is necessary as they can contribute to efficiency. It is only through user satisfaction evaluation that their requirements can be made known. Users are the direct beneficiaries of the service. They are the only people who can define the quality of the service they are receiving. Getting them involved will not only result in

Lateef, O A, Khamidi, M F and Idrus, A (2010) 'Building maintenance management in a Malaysian university campuses: a case study', Australasian Journal of Construction Economics and Building, 10 (1/2) 76-89 
commitment to efficient services but also influence the service delivery. Apart from the fact that users create their value systems, they have the ability to bring their requirements to notice and to take action if their requirements are not fulfilled (see Soderholm, Holmgren and Klefsjo, 2007). Users need to be questioned on the services they are provided with. The findings of the evaluation or survey could be the basis of meaningful performance measurement and management.

13. The dockets are haphazardly completed. For instance, sometimes the docket is filled in prior to the commencement of the repair, while it is sometimes filed after the works have been completed leading to inconsistencies. In a book of dockets, often one could find dockets issued for work done in January preceded by those issued in March. As a matter of fact, the information in the docket is not reliable and not all the works in the docket are executed or implemented. It is therefore difficult to rely on the information in the docket to track complaints, assess the size of work done and other decision making information.

\section{Concluding Comments}

The paper reviewed related literature and presented the outcome of a case study on university organization. The data obtained through the case study revealed a number of shortcomings with building maintenance management in a university organization in Malaysia. Despite the significance of maintenance management, many academic organizations view building maintenance and building maintenance management as a burden rather than as a value added strategy. Hence its current status in university management processes. Maintenance management is not regarded as part of the top management function or duties but as an operational function. It only receives management attention when everything has gone wrong. Ultimately, users are not satisfied with the quality of the service they are receiving leading to increased maintenance backlogs. The case study also shows that the major reason why the university focuses more on corrective maintenance was a result of budget constraints and the lack of a competent workforce. Deferring maintenance is not effective as the component will continue to degenerate until such a time that the building could be unsafe for use. Even if it is repaired before this critical stage, the amount of work involved will have been more and the users will be frustrated with the outcome of the services. Building users, as the entity or group of individuals or the organisation, are interested in the adequate functioning of the building, a failing in which increases their dissatisfactions. They are affected by the performance of the building. The inadequacies with the maintenance of the system of the university suggests that there is a need for a maintenance management framework capable of guiding maintenance organisations to ensure that whenever maintenance is initiated and implemented it is consistence, systematic and holistic. Building maintenance management involves the establishment of a framework for the maintenance of buildings and its associated services and the upkeep of the building performance. Although the conclusion drawn is based on a case study, the situation is likely to be similar in most university organisations.

\section{References}

Barker, S. (2005) 'Business graduates as end-user developers: understanding information literacy skills required'. in Technology Literary Application in Learning Environments D. Garbonara, (ed): Information Science Publishing, USA

Bell, J. (2005) Doing Your Research Project: A Guide for First Time Researchers in Education, Health and Social Science, $4^{\text {th }}$ Edition, Open University Press, London

Boyd, D. and Chinyio, E. (2006) Understanding the Construction Client, Blackwell Publishing, NY

Campbell, J. D. (1995) 'Outsourcing in maintenance management: A valid alternative to selfprovision', Journal of Quality in Maintenance Engineering, 1 (3), 18-24 
Fellows, R and Liu, A. (2008) Research Methods for Construction, $3^{\text {rd }}$ Ed. Blackwell Publishing, Oxford

Fianchini, M. (2007) 'A performance evaluation methodology for the management of university buildings', Facilities, 25 (3/4), 137 - 146

Flanagan, R. and Jewell, C. (2005) Whole Life Appraisal for Construction, Blackwell Publishing, Oxford

Fleming, D. and Storr, J. (1999) 'The impact of lecture theatre design on learning experience', Facilities, 17 (7/8) 231 - 236

Green, D. and Turrell, P. (2005) 'Schools buildings investment and impact on pupil performance', Facilities, 23 (5/ 6), 253 - 261

Government of Malaysia, (1991) Sixth Malaysian Plan 1991-1995, Economic Planning Unit, Prime Minister's Department, Putrajaya

Government of Malaysia, (1996) Seventh Malaysian Plan 1996-2000, Economic Planning Unit, Prime Minister's Department, Putrajaya

Government of Malaysia, (2001) Eighth Malaysian Plan 2001-2005, Economic Planning Unit, Prime Minister's Department, Putrajaya

Government of Malaysia, (2006) Ninth Malaysian Plan 2006-2010, Economic Planning Unit, Prime Minister's Department, Putrajaya

Housley, J. (1997) 'Managing the estate in higher education establishments', Facilities, 15 (3/4), 72 - 83

Jones, K. and Sharp, M. (2007) 'A new performance based process model for built asset maintenance', Facilities, 25 (13/14), 525-535

Lavy, S. and Bilbo, D.L. (2009) 'Facilities maintenance management in large public schools', Texas' Facilities, 27 (1 / 2), 5-20

Leung, M and Fung, I. (2005) 'Enhancement of classroom facilities of primary schools and its impact on learning behaviors of students', Facilities, 23 (13/14) 585- 594

Komu, F. (2008) 'Quality housing and its influence on house consumers' behaviour', in Proceedings of The Construction and building research conference of the Royal Institution of Chartered Surveyors (COBRA), 2008), Dublin Institute of Technology, 4-5 September 2008, available at www.rics.org/cobra.

Martin, H.H. (1997) 'Contracting out maintenance and a plan for future research', Journal of Quality in Maintenance Engineering, 3 (2), 81-90

Mat, S., Sopian, K., Moktar, M., Hashim, S.H., Abdul Rashid, A., Zain, M.F.M. and Abdullah, G. N. (2009) 'Managing sustainable campus in Malaysia - organizational approach and measures', European Journal of Social Science, 8 (2), 201- 214

McNiff, J. (1992) Action Research: Principles and Practices, Routledge, London

Mills, E.D. (1994) (ed.) Building Maintenance and Preservation; a Guide to Design and Management, $2^{\text {nd }}$ ed, Butterworth-Heinemann, Oxford

Ministry of Higher Education, (2006) Towards Excellence Report: Report by the Committee to Study, Review and Make Recommendations Concerning the Development and Direction of Higher Education in Malaysia, University Publication Centre, University Technology Malaysia, Shah Alam

Naoum, G.S. (2004) Dissertation Research and Writing for Construction Students. Elsevier Butterworth- Heinemann, Oxford

New Straits Times (2009 4 Mar) 'RM3.2 billions contracts to be awarded', Prime News

Lateef, O A, Khamidi, M F and Idrus, A (2010) 'Building maintenance management in a Malaysian university campuses: a case study', Australasian Journal of Construction Economics and Building, 10 (1/2) 76-89 
$\mathrm{Ng}$, C.S.P, Gable, G. and Chan, T. (2003) 'An ERP maintenance model', in Proceeding of the $36^{\text {th }}$ Hawaii International Conference on System Sciences (HICSS"03) 0-7695-1874-5 I 03

O'Dell, A. (1996) 'Taking stock: A review of stock condition survey methods in the UK', Useroriented and Cost Effective Management, Maintenance and Modernization of Building Facilities, CIB W70, Kesinki 1996 Symposium, 2-3 Sep

Olanrewaju, A. A. (2009) 'Maintenance management of university buildings', accepted for publication in Journal of Building Appraisal

Price, I.F., Matzdorf, F., Smith, L. and Agahi, H. (2003) 'The impact of facilities on the student choice of university', Facilities, 21 (10), 212 -222

Umeadi, B.B.N and Jones, K.G. (2003) 'From condition to performance assessment of built component', In Proceedings of The RICS Foundation Construction and Building Research Conference COBRA, ed D. Proverbs, School of Engineering and the Built Environment, University of Wolverhampton, 1-2 Sep

Sherwin, D. (2000) 'A review of overall models for maintenance management', Journal of Quality Maintenance Engineering, 6 (3), 138-164

Shohet, I. G., Lavy-Leibovich, S. and Bar-On, D. (2003) 'Integrated maintenance monitoring of hospital buildings' Journal of Construction Management and Economics, 21, 219 - 228

Soderholm, P. Holmgren, M. and Klefsjo, B. (2007) 'A process view of maintenance and its stakeholders', Journal of Quality in Maintenance Engineering, 13(1), 19 -32

Tapsir, H.S. (2005) 'Strategy for sustainability in affordable housing_a challenge to Malaysia construction industry', in Proceedings of the 2005 World Sustainable Buildings Conference, Tokyo $27-29$ Sep

The Star, (2009 March 23) Billion Ringgit Projects, N4

The Star, (2009 April 28) Early Ageing, M2 - M3

Then, S.S. (2002) 'Post -occupancy evaluation'; in: Best Value In Construction, J. Kelly, R. Morledge and S. Wilkinson eds. Blackwell Publishing, London

Wood, S and Worthing, D. (1996) 'Post-occupancy evaluation of higher education buildings; a case study, The cutting edge', RICS Research

Wong, W.P., Fellows, R.F. and Liu, A.M.M. (2006) 'Use of electrical energy in university buildings: a Hong Kong case study', Facilities, 24 (1/ 2), 5 -17

Tsang, A.H.C. (2002) 'Strategic dimensions of maintenance management', Journal of Quality in Maintenance Engineering, 8 (1), 70- 39 